\title{
Kinetic Analysis of the Oxidation of Ascorbic Acid in an Open Reactor with Gas Bubbling
}

\author{
Osato MIYAWAKI $^{\dagger}$, Taira SUGIYAMA, Erika INOUE \\ Department of Food Science, Ishikawa Prefectural University, \\ 1-308 Suematsu, Nonoichi, Ishikawa 921-8816, JAPAN
}

\begin{abstract}
An open reactor with gas bubbling with various oxygen partial pressure was applied to investigate the role of oxygen in the oxidation of ascorbic acid (AA). The reaction kinetics was described well by the zero-th order mechanism and the rate constant was exactly proportional to the oxygen partial pressure but no effect of initial AA concentration was observed. The reaction rate increased with an increase in $\mathrm{pH}$ and decreased by the addition of EDTA as a chelating agent to trace metals suggesting the involvement of metals in the AA oxidation process. The temperature dependence of the kinetics was measured from 0 to $70^{\circ} \mathrm{C}$ and the activation energy was obtained to be $62.1 \mathrm{~kJ} / \mathrm{mol}$. On the contrary, the AA oxidation was described by the 1-st order kinetics in a closed reactor system because of the limiting oxygen supply. From these results, the aerobic AA oxidation scheme was estimated with the reaction between molecular oxygen and AA as a limiting step.
\end{abstract}

Keywords: kinetic analysis, oxidation of ascorbic acid, oxygen partial pressure, zero-th order kinetics

\section{Introduction}

As ascorbic acid (AA) is an important food ingredient, its stability in processing and storage has attracted many researchers interest. Therefore, many kinetic analyses for the stability of AA have been carried out [1] but still there is controversy and no established theory is available. Metal ion and metal chelate catalyzed oxidation of AA was investigated and the catalytic contribution of cupric and ferric chelate was clarified but no effect of oxygen partial pressure was reported [2].

Wilson et al. [3] comprehensively carried out a kinetic study of the oxidation process of AA in solution using an isothermal microcalorimeter. They found that the oxidation reaction of AA was described by the 1-st order kinetics with respect to the oxygen concentration. The reaction rate was found to increase with $\mathrm{pH}$, oxygen concentration and with coexistence of metals.

As for nonthemal processing, high pulsed electric field treatment was applied to orange-carrot juice [4] and orange juice-milk beverage [5]. Degradation process of $\mathrm{AA}$ in the processing was described by the zero-th order kinetics in the former while the 1-st order kinetics was applied in the latter. Sonication was applied to orange juice and the 1-st order kinetics was applied [6].

(Received 17 Feb. 2016: accepted 17 May. 2016)

$\dagger$ Fax: +81-76-227-7410, E-mail: osato@ishikawa-pu.ac.jp
In the long time storage, AA degradation has been described by the 1-st order kinetics for orange-carrot juice [4] and blood orange juice [7] while the zero-th order kinetics was applied for orange juice-milk beverage [5] and orange, grape, and pomegranate juices, and sour cherry nectar [8]. Among these investigations, many researchers pointed out the important role of oxygen $[3,9,10]$ and the use of oxygen scavenger material was proved to be effective for the preservation of $\mathrm{AA}$ [10].

In the present paper, we apply an open reactor with gas bubbling with the oxygen partial pressure controlled from 0 to $100 \%$ to investigate the role of oxygen in $\mathrm{AA}$ oxidation process directly.

\section{Experimental}

\subsection{Materials and sample preparation}

Ascorbic acid sodium salt was purchased from Nacalai Tesque (Kyoto). Acetonitrile, acetic acid, disodium dihydrogen ethylenediamine tetraacetic dehydrate (EDTA$2 \mathrm{Na}$ ), and ethylene tetraacetic acid tetrasodium salt tetrahydrate (EDTA-4Na) were obtained from Kanto Kagaku (Tokyo). All other reagents used were of reagent grade. Gas containing $0\left(\mathrm{~N}_{2}\right)$, 5, 20 (air), 50, and 100\% oxygen gas in a cylinder was supplied by Uno Sanso (Fukui). 


\subsection{Open reactor with gas bubbling}

To a $100 \mathrm{~mL}$ three neck flask kept in a water bath at a controlled temperature $\left(0\right.$ to $\left.70^{\circ} \mathrm{C}\right), 100 \mathrm{~mL}$ of ascorbic acid (AA) sodium salt at various concentrations $(0.1$ to $0.5 \mathrm{~g} / \mathrm{L}$ ) dissolved in a buffer solution ( $\mathrm{pH}: 4-8)$ was added and gas containing a certain oxygen level was introduced and was mildly bubbled through a teflon tube to start the reaction. The AA solution was sampled at intervals to analyze AA. A buffer with $1 / 15 \mathrm{M} \mathrm{KH}_{2} \mathrm{PO}_{4}{ }^{-}$ $1 / 15 \mathrm{M} \mathrm{Na}_{2} \mathrm{HPO}_{4}$ was used for $\mathrm{pH} 6$ and 8, and $0.05 \mathrm{M}$ potassium hydrogen citrate $-0.1 \mathrm{~N} \mathrm{NaOH}$ was used for $\mathrm{pH} 4$.

\subsection{Closed reactor system}

To $100 \mathrm{~mL}$ of $0.15 \mathrm{~g} / \mathrm{L}$ ascorbic acid (AA) sodium salt dissolved in Sorensen buffer at pH8.0 (1/15 $\mathrm{M} \mathrm{KH}_{2} \mathrm{PO}_{4}$ $1 / 15 \mathrm{M} \mathrm{Na}_{2} \mathrm{HPO}_{4}$ ), air was bubbled for $5 \mathrm{~min}$ to saturate oxygen. Then, the solution was poured into $8 \mathrm{~mL}$ glass tubes with minimum head space and sealed with screw caps. Tubes were kept in a heat block (Dry Thermo Unit DTU-1C, Taitech Corporatiion, Saitama) at a controlled temperature to start the reaction and were taken out at intervals to analyze AA.

\subsection{Assay of ascorbic acid}

A $20 \mu \mathrm{L}$ sample was directly injected into a HPLC system (PU-980 HPLC pump, UV-970, Jasco, Tokyo) with a column (Inertsil- $\mathrm{NH}_{2}$, GL Sciences, Tokyo) eluted by acetonitrile: $\mathrm{H}_{2} \mathrm{O}$ : acetic acid=87:11:2 at a flow rate of 2 $\mathrm{mL} / \mathrm{min}$ detected at $243 \mathrm{~nm}$. The LC chromatogram was processed by a software (Chromato-Pro, Runtime Instrument, Kanagawa).

\section{Results and Discussion}

\subsection{Kinetic analysis of AA oxidation in open reactor with gas bubbling}

\subsubsection{Kinetics analysis}

Figure $1 \mathrm{~A}$ and $1 \mathrm{~B}$ show the degaradation kinetics of AA with a bubbling by air at $70^{\circ} \mathrm{C}$ with $\mathrm{pH} 6.0$ described by the zero-th order (Eq.(1)) and the 1-st order kinetics (Eq.(2)), respectively.

$$
\begin{gathered}
C_{A} / C_{A O}=1-\left(k_{0} / C_{A O}\right) t \\
C_{A} / C_{A O}=\exp \left(-k_{1} t\right)
\end{gathered}
$$

where $C_{A}$ is AA concentration at a time $t, C_{A O}$ is that at the initial state, and $k_{0}$ and $k_{1}$, respectively, are the rate constants in the zero-th order and the 1-st order kinetics. It is evident that the zero-th order kinetics fits exper-
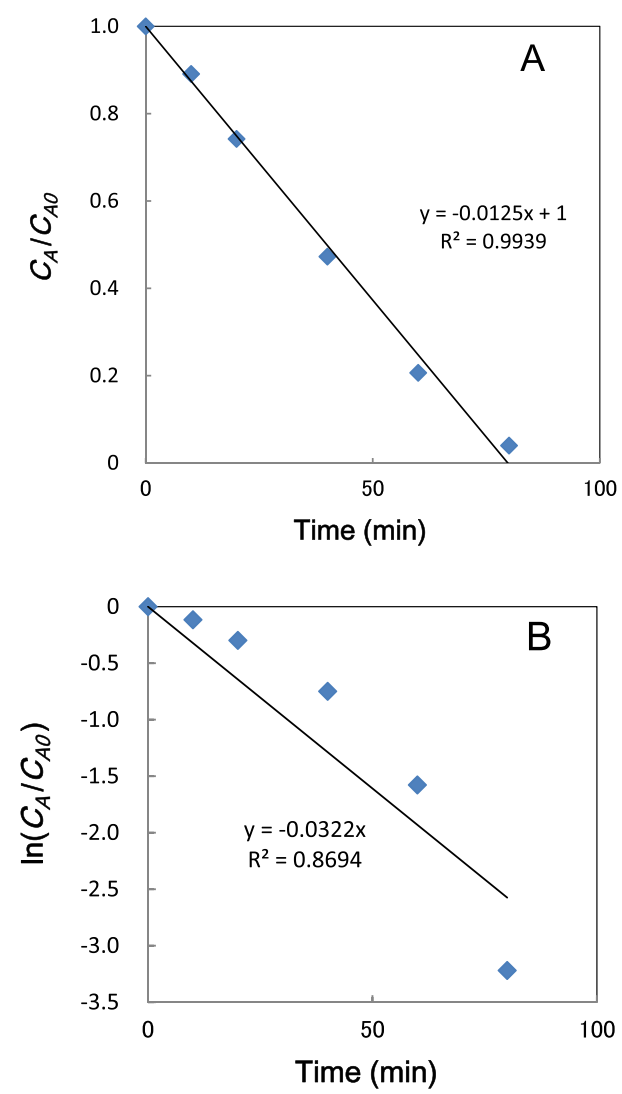

Fig. 1 Kinetic analysis of AA oxidation at $70^{\circ} \mathrm{C}$ with air bubbling at $\mathrm{pH} 6.0$ described by the zero-th order (A) and the 1-st order kinetics (B). Initial AA concentration was $0.15 \mathrm{~g} / \mathrm{L}$.

imental data much better in the present case.

\subsubsection{Effect of AA concentration}

Effect of AA concentration on AA stability is shown in Fig. 2. Apparently, no effect of AA concentration is observed. In the present case, saturated oxygen concentration is $0.187 \mathrm{mM}$ while the lowest $\mathrm{AA}$ concentration in the experiment was $0.505 \mathrm{mM}$ so that AA concentration cannot limit the initial process. The similar situation frequently occurs in the preservation of fruits juices, which contain much higher AA concentration [11].

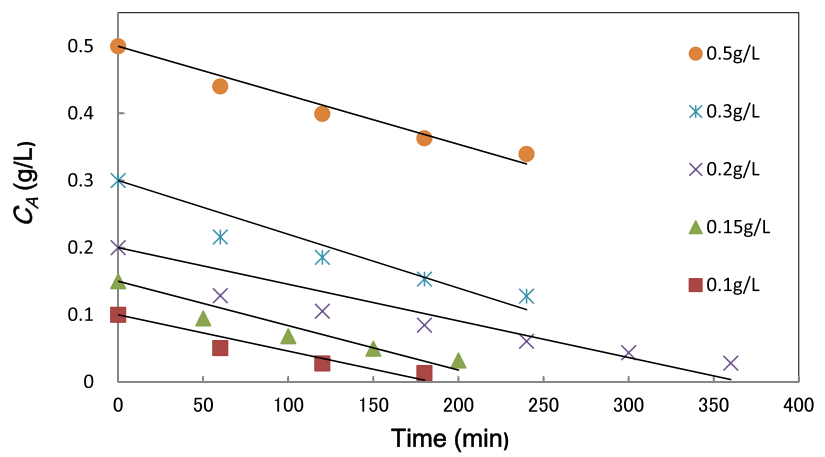

Fig. 2 Effect of initial AA concentration on the oxidation rate of $\mathrm{AA}$ at $50^{\circ} \mathrm{C}$ with air bubbling at $\mathrm{pH}$ 8.0. 


\subsubsection{Effect of oxygen partial pressure}

Effect of oxygen partial pressure on AA oxidation rate is shown in Fig. 3. The reaction rate was strongly affected by $\mathrm{O}_{2}$ concentration. From the slope of this plot, the zero-th order kinetic parameter, $k_{0} / C_{A O}$ was obtained. This parameter was plotted to oxygen concentration as shown in Fig. 4. An excellent linear relationship was observed, which shows that the oxygen supply is the limiting step in AA oxidation.

\subsubsection{Effect of $\mathrm{pH}$}

Figure 5 shows the effect of $\mathrm{pH}$ on AA oxidation rate at

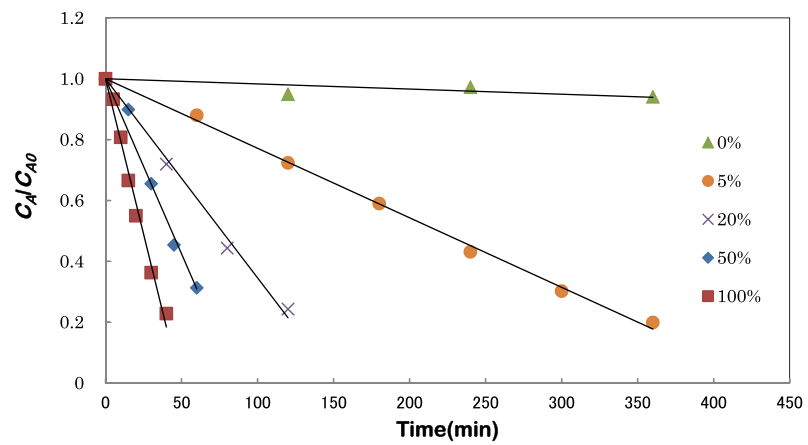

Fig. 3 Effect of oxygen partial pressure on AA oxidation rate at $50^{\circ} \mathrm{C}$ at $\mathrm{pH} 8.0$ with bubbling gas with various $\mathrm{O}_{2}$ partial pressure. Initial AA concentration was $0.15 \mathrm{~g} / \mathrm{L}$.

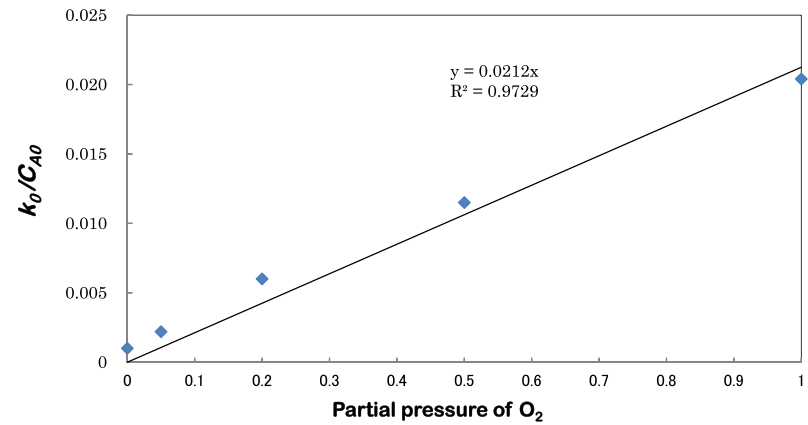

Fig. 4 Effect of oxygen partial pressure on the zero-th order rate constant, $k_{0}$, for $\mathrm{AA}$ oxidation at $50^{\circ} \mathrm{C}, \mathrm{pH}$ 8.0. Initial $\mathrm{AA}$ concentration was $0.15 \mathrm{~g} / \mathrm{L}$.

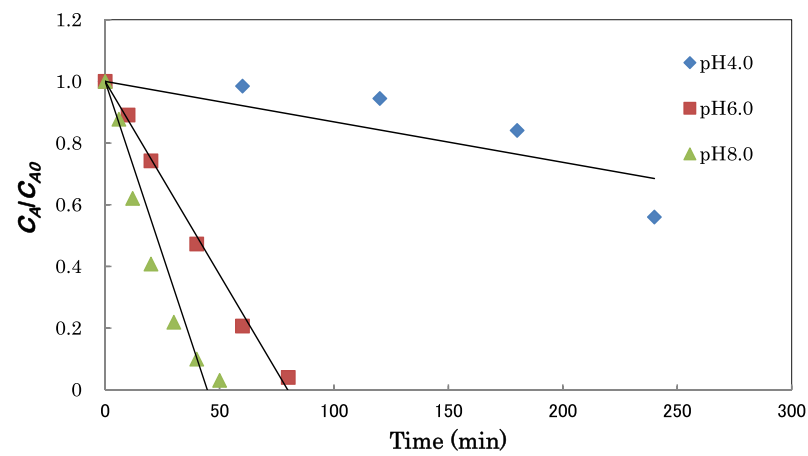

Fig. 5 Effect of $\mathrm{pH}$ on $\mathrm{AA}$ oxidation rate at $70^{\circ} \mathrm{C}$ with air bubbling. Initial AA concentration was $0.15 \mathrm{~g} / \mathrm{L}$. $70^{\circ} \mathrm{C}$ with air bubbling. The reaction rate increase markedly with an increase in $\mathrm{pH}$. In fruits juice, $\mathrm{pH}$ is mostly around 4

\subsubsection{Effect of trace metal}

At the initial step of the AA oxidation, an important role of trace metals have been reported [2,3]. Therefore, the effect of EDTA addition was carried out to chelate trace metals. As shown in Fig. 6, with addition of EDTA, the AA oxidation rate decreased showing the contribution of trace metals.

\subsubsection{Effect of temperature}

Figure 7 shows the effect of temperature from 0 to $70^{\circ} \mathrm{C}$ on the zero-th order rate constant of AA oxidation in the form of Arrhenius plot. A good linear correlation was obtained and from this plot, the activation energy for AA oxidation reaction was obtained to be $62.1 \mathrm{~kJ} / \mathrm{mol}$, which is a typical value as a chemical process.

\subsection{Kinetic analysis of AA oxidation in closed reactor}

Figure 8 shows the kinetic analysis of AA oxidation in closed reactor. Air was introduced to the reaction mixture and bubbled for $5 \mathrm{~min}$ at the beginning then sealed to start the reaction at each temperature. In this case,

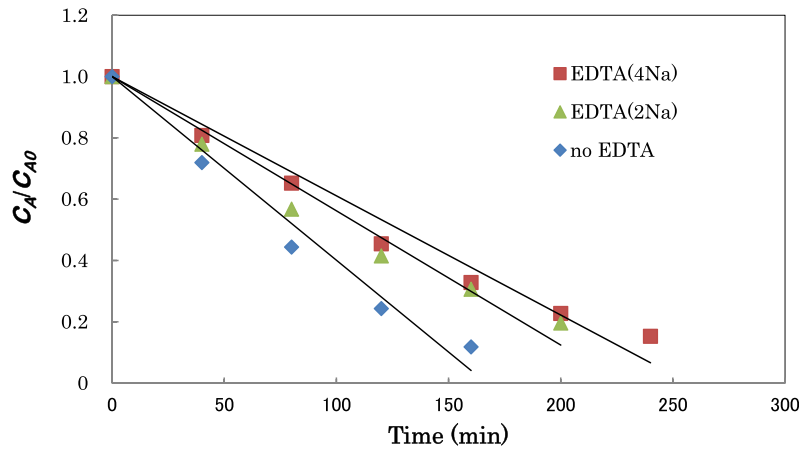

Fig. 6 Effect of EDTA addition on AA oxidation rate at $50^{\circ} \mathrm{C}$ with air bubbling at $\mathrm{pH}$ 8.0. Initial $\mathrm{AA}$ concentration was $0.15 \mathrm{~g} / \mathrm{L}$.

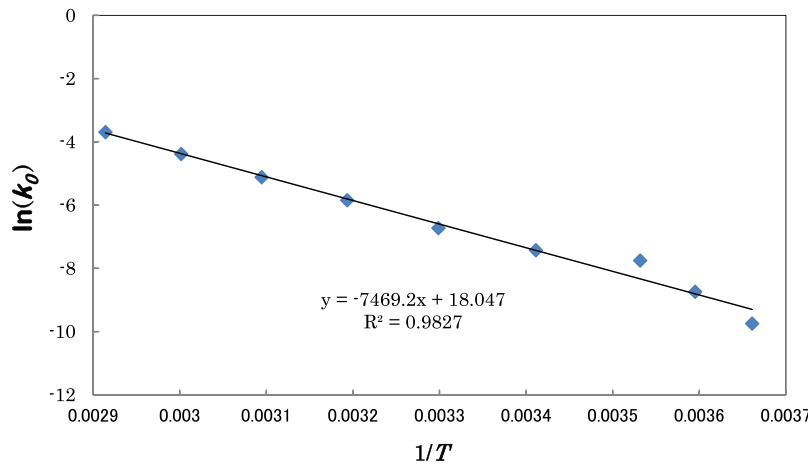

Fig. 7 Effect of temperature on AA oxidation rate at $\mathrm{pH} 8.0$ with air bubbling. Initial AA concentration was $0.15 \mathrm{~g} / \mathrm{L}$ 


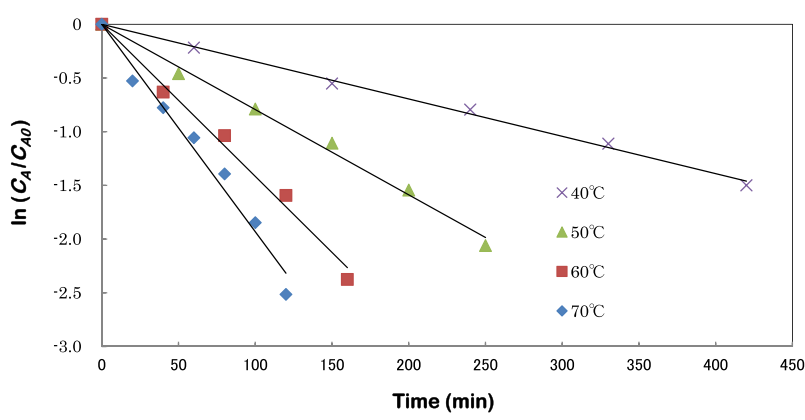

Fig. 8 Kinetic analysis of AA oxidation in closed reactor system at $\mathrm{pH}$ 8.0. To the reaction mixture air was introduced and bubbled at the beginning for $5 \mathrm{~min}$ then sealed. Initial AA concentration was $0.15 \mathrm{~g} / \mathrm{L}$.

the 1-st order kinetics was applicable because oxygen is consumed stoichiometrically in the AA oxidation process as follows [3].

$$
\mathrm{d}\left[\mathrm{O}_{2}\right] / \mathrm{d} t=k_{1}\left[\mathrm{O}_{2}\right]
$$

In the closed reactor system, $\left[\mathrm{O}_{2}\right]$ decreased with time because it was consumed so that the 1 -st order kinetics were observed while $\left[\mathrm{O}_{2}\right]$ was constant in the open reactor system so that the zero-th order kinetics were observed. From the temperature dependency of $k_{1}$ in Fig. 8, the activation energy was obtained from the Arrhenius plot (data not shown) to be $51.2 \mathrm{~kJ} / \mathrm{mol}$, which is not different from the former case with the open reactor. This correspondence between the two shows that the same chemical reaction proceeds irrespective to openness or closedness of the reactor.

\subsection{Scheme of AA oxidation in aerobic}

\section{conditions}

From the above results, the AA oxidation scheme is shown in Fig. 9, which has been basically proposed by Wilson et al. [3] from the kinetic analysis of AA oxidation by the closed reactor system using an isothermal microcalorimeter. In the present case, we applied open reactor system with gas bubbling to control the oxygen partial pressure directly and obtained a similar scheme. Effect of trace metal works at the initial step to pull-out hydrogen molecule from reduced AA to form monoanion ascorbic acid. Effect of pH will be also related to this step. Then, molecular oxygen attacks monoanion ascorbic acid to form ascorbate radical anion which spontaneously turn to dehydroascobic acid. The dehydroascobic acid can be reduced by mild reducing agent to reduced AA so this reportedly works as vitamin C. However, dehydroascorbic acid is not readily absorbed across the intestinal mucosa [9] so that active vitamin $\mathrm{C}$ would be mainly

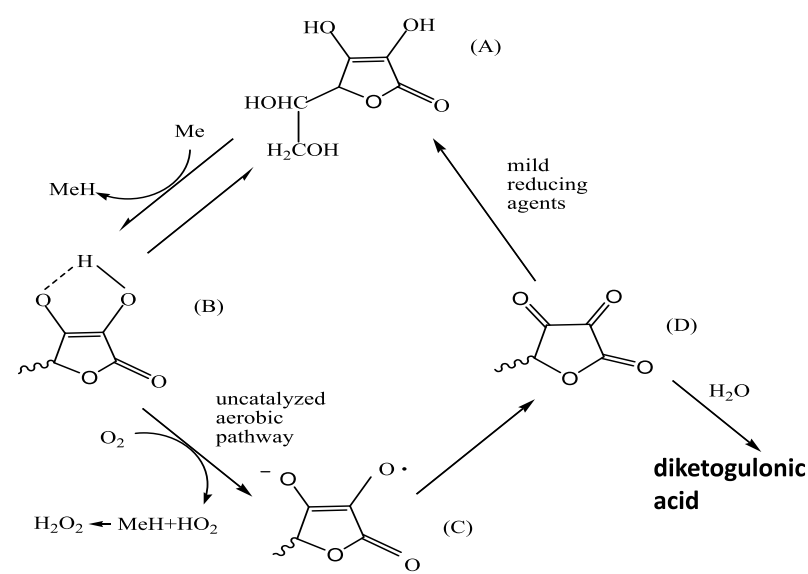

(A)reduced ascorbic acid (C)ascorbate radical anion

monoanion ascorbic acid (D)dehydroascorbic acid

Fig. 9 Reaction scheme of AA oxidation in aerobic condition.

reduced AA. Dehydroascorbic acid also changes to diketogulonic acd, which has no vitamin $\mathrm{C}$ activity anymore.

In the above scheme of AA oxidation, the limiting step as a whole is the reaction between molecular oxygen and monoanion ascorbic acid. When oxygen is sufficiently available like in the present open reactor system, the reaction proceeds in the zero-th order kinetics while oxygen supply is limited like the closed reactor system, the AA oxidation proceeds in the 1-st order kinetics. In the long time preservation of food, the situation will be the same. In some reports, 1-st order kinetics have been applied but in others zero-order kinetics were employed. In the latter case, however, the oxygen supply into the package might have some role in the preservation.

\section{Conclusions}

An open reactor with gas bubbling with various oxygen partial pressure was effective to investigate the role of oxygen directly in AA oxidation process. The reaction kinetics were described well by the zero-th order mechanism and the rate constant was exactly proportional to the oxygen partial pressure. The reaction rate increased with an increase in $\mathrm{pH}$ and decreased by the addition of EDTA as a chelating agent to trace metals suggesting the involvement of metals in the process. With change in temperature from 0 to $70^{\circ} \mathrm{C}$, the activation energy was obtained to be $62.1 \mathrm{~kJ} / \mathrm{mol}$. On the contrary, the reaction kinetics were described by the 1-st order kinetics in a closed reactor system because of the limiting oxygen supply. From these results, keeping out oxygen and low temperature operation are effective to preserve AA in the processing and storage. 


\section{References}

1) S. R. Tannenbaum, V. R. Young; "7. Vitamins and minerals" in Food Chemistry, O. R. Fennema ed., Marcel Dekker, New York, 1985, pp. 477-495.

2) M. M. Taqui Khan, A. E. Mertell; Metal Ion and Metal Chelate Catalyzed Oxidation of Ascorbic Acid by Molecular Oxygen. II .Cupric and Ferric Chelate Catalyzed Oxidation. J. Am. Chem. Soc., 89:26, 7104-7111 (1967).

3) R. J. Wilson, A. E. Beezer, J. C. Mitchell; A kinetic study of the oxidation of $\mathrm{L}$-ascorbic acid (vitamin $\mathrm{C}$ ) in solution using an isothermal microcalorimeter. Thermochim. Acta, 264, 27-40 (1995).

4) F. Torregrosa, M. J. Steve, A. Frigola, C. Cortes; Ascorbic acid stability during refrigerated storage of orange-carrot juice treated by high pulsed electric field and comparison with pasteurized juice. J. Food Eng., 73, 339-345 (2006).

5) A. Zulueta, M. J. Esteve, A. Frigola; Ascorbic acid in orange juice-milk beverage by high intensity pulsed electric fields and its stability during storage. Innov. Food Sci. Emerg. Technol., 11, 84-90 (2010).
6) B. K. Tiwari, C. P. O' Donnell, K. Muthukumarappan, P. J. Cullen; Ascorbic acid degradation kinetics of sonicated orange juice during storage and comparison with thermally pasteurized juice. LWT-Food Sci. Technol., 42, 700-704 (2009).

7) B. Torres, B. K. Tiwari, A. Patras, P. J. Cullen, N. Brunton, C. P. O' Donnell; Stability of anthocyanins and ascorbic acid of high pressure processed blood orange juice during storage. Innov. Food Sci. Emerg. Technol., 12, 93-97 (2011).

8) M. Ozkan, A. Kirca, B. Cemeroglu; Effects of hydrogen peroxide on the stability of ascorbic acid during storage in various fruit juices. Food Chemistry, 88, 591-597 (2004).

9) C. S. Johnston; Stability of ascorbic acid in commercially available orange juices. J. Am. Dietet. Assoc., 102, 525-529 (2002).

10) K. Zerdin, M. L. Rooney, J. Vermue; The vitamin C content of orange juice packed in an oxygen scavenger material. Food Chemistry, 82, 387-395 (2003).

11) M. Yamaguch (Ed.), "Gotei Shokuhin-Seibun-Hyo" (in Japanese), Ishiyaku Publishers, Tokyo, Japan, 2001. 


\title{
ガス通気開放型反応器を用いたアスコルビン酸酸化反応の 速度論的解析
}

\author{
宮脇長人 ${ }^{\dagger}$, 杉山 平, 井上絵里加 \\ 石川県立大学生物資源環境学部食品科学科
}

酸素分压を種々に変化させたガスを用いた通気開放 型反応器を用いてアスコルビン酸 $(\mathrm{AA})$ 酸化反応の速度 論定解析を行った. 反応速度は零次反応で記述でき, 零次反応速度定数は酸素分圧に完全に比例したが，初 期 $\mathrm{AA}$ 濃度には全く影響されなかった。 反応速度は $\mathrm{pH}$ の上昇に伴い上昇，また，EDTAの添加により減少し， このことは, $\mathrm{AA}$ 酸化反応における微量金属の関与を窺
わせた. 温度を $0^{\circ} \mathrm{Cから} 70^{\circ} \mathrm{C}$ まて変化させて活性化工 ネルギーを求めた結果, $62.1 \mathrm{~kJ} / \mathrm{mol}$ となった。一方, ガス通気をしない閉鎖型反応器に扔いては反応速度は 一次反応であった。 以上の結果に基づいて, AA と分子 状酸素との反応を律速段階とする好気条件での AA 酸 化反応機構を推定した. 